\title{
Hygienic-sanitary working practices and implementation of a Hazard Analysis and Critical Control Point (HACCP) plan in lobster processing industries
}

\author{
Condições higiênico-sanitárias e implementação do plano de Análise de Perigos e Pontos Críticos de Controle \\ (APPCC) em indústrias processadoras de lagosta
}

\author{
Cristina Farias da FONSECA ${ }^{1}$, Tânia Lúcia Montenegro STAMFORD², Samara Alvachian Cardoso ANDRADE², \\ Evandro Leite de SOUZA ${ }^{4}$, Celiane Gomes Maia da SILVA ${ }^{1 *}$
}

\begin{abstract}
This study aimed to verify the hygienic-sanitary working practices and to create and implement a Hazard Analysis Critical Control Point (HACCP) in two lobster processing industries in Pernambuco State, Brazil. The industries studied process frozen whole lobsters, frozen whole cooked lobsters, and frozen lobster tails for exportation. The application of the hygienic-sanitary checklist in the industries analyzed achieved conformity rates over $96 \%$ to the aspects evaluated. The use of the Hazard Analysis Critical Control Point (HACCP) plan resulted in the detection of two critical control points (CCPs) including the receiving and classification steps in the processing of frozen lobster and frozen lobster tails, and an additional critical control point (CCP) was detected during the cooking step of processing of the whole frozen cooked lobster. The proper implementation of the Hazard Analysis Critical Control Point (HACCP) plan in the lobster processing industries studied proved to be the safest and most cost-effective method to monitor each critical control point (CCP) hazards.

Keywords: fishery industry; good manufacturing practices; HACCP; food safety.
\end{abstract}

\section{Resumo}

Objetivou-se com este estudo verificar as condições higiênico-sanitárias e criar um plano de Análise de Perigos e Pontos Críticos de Controle (APPCC) para implantação em duas indústrias de processamento de lagosta no Estado de Pernambuco, Brasil. As indústrias estudadas processam lagosta inteira congelada, lagostas inteiras cozidas congeladas e caudas de lagosta congelada para exportação. A aplicação de um checklist de controle higiênico-sanitário nas indústrias visitadas resultou em uma classificação global de conformidades maior que $96 \%$ dos aspectos analisados. O desenvolvimento do plano APPCC resultou na detecção de dois pontos críticos de controle (PCC), incluindo o recebimento e etapas de classificação, no processamento de lagosta congelada e caudas de lagosta congelada, e um PCC adicional foi detectado no processamento de lagosta inteira cozida congelada na etapa de cozimento. A correta implantação do plano APPCC nas indústrias de processamento de lagosta estudadas demonstrou ser o método mais seguro e efetivo economicamente para o controle dos perigos em cada PCC. Palavras-chave: indústria de pescado; boas práticas de manipulação; APPCC; segurança alimentar.

\section{Introduction}

Lobster is one of the most important fishing resources in the northeastern Brazil. This region has exported this product to the USA, Japan, and Europe in the form of frozen whole lobsters, frozen whole cooked lobsters, and frozen lobster tails since the early 1960s. In 2008, the annual production in Brazil was approximately 2,500 tons of lobster tails and approximately 500 tons of whole lobsters. The production of lobster tails is mainly exported to the USA, and whole lobsters are exported mainly to Japan and Europe (OGAWA; ITÓ; MELO, 2007; SOMOZA et al., 2008). In Brazil, the three most commonly harvested species of spiny lobsters (Palinuridae) are: Panulirus argus (Latreille 1804), P. laevicauda (Latreille 1817) and P. echinatus (Smith 1869). P. argus and P. laevicauda account for approximately 75 and 20\%, respectively, of the total production. Two of these species ( $P$. argus and $P$. laevicauda) are protected by fishery regulations, such as minimum size of capture and allowed periods of capture, whereas $P$. echinatus does not have legal management due to the lack of biological information (GÓES; LINS-OLIVEIRA, 2009).

The production model of some lobster processing plants in Brazil still presents problems related to the inappropriate handling in fishery boats, thus decreasing the quality of the incoming lobsters as a consequence of microbial spoilage and melanosis. This reality has prompted some industries to include chemical additives, such as sodium chlorine and sodium metabisulfite, in their products to delay these post-mortem

\footnotetext{
Received 27/6/2012

Accepted 16/11/2012(005705)

${ }^{1}$ Post-Graduate Program of Food Science and Technology, Department of Domestic Sciences, Rural Federal University of Pernambuco - UFRPE, CEP 52171-900, Recife, PE, Brazil,e-mail: celianemaia@yahoo.com.br

${ }^{2}$ Department of Nutrition, Health Sciences Center, Federal University of Pernambuco - UFPE, Recife, RE, Brazil

${ }^{3}$ Department of Chemical Engineering, Technology and Geosciences Center, Federal University of Pernambuco - UFPE, Recife, PE, Brazil

${ }^{4}$ Department of Nutrition, Health Sciences Center, Federal University of Paraíba - UFPB, João Pessoa, PB, Brazil

${ }^{*}$ Corresponding author
} 
changes. Therefore, it is difficult for the Brazilian lobster industries to compete in the international market due to the difference in price, which favors the products from other processing countries. The low quality of lobsters processed by some Brazilian industries has been responsible for the loss of important markets for exportation and, in some occasions, the devolution of products processed in Brazil.

As a consequence and due to the current sanitary regulations, some Brazilian lobster processing industries have implemented prevention and risk control measures in their production line based on the Hazard Analysis and Critical Control Point (HACCP) system. According to Lupin, Parim and Zugarramund (2010), there is worldwide interest in the implementation of the HACCP system by the food industry, especially for high-risk foods such as fishery products.

The HACCP system is an effective way to manage the production of high-quality foods that emphasizes the prevention of possible chemical, physical, and biological hazards during processing (BELL et al., 2009; POUMEYROL et al., 2010). However, the HACCP system success and efficacy in preventing foodborne diseases and risks to consumer's health depend on the proper application of its principles combined with other programs including safety infrastructure as well as the Good Manufacturing Practice and Sanitation Standard Operational Procedures (GMP/SSOP) (ROBERTO; BRANDÃO; SILVA, 2006). The proper implementation of the HACCP system could identify and assess the potential risks associated with storage, manufacture, and delivery of foods as well as the appropriate effective measures to eliminate or reduce the hazard in specific stages of production (YOUN; SNEED, 2003; WANG et al., 2010; ZIGGERS, 2000).

This study aimed to verify the hygienic-sanitary working practices in two lobster processing Brazilian industries and to design a HACCP plan for these industries to develop an appropriate hazard control method for their production lines.

\section{Materials and methods}

This study was conducted in the two major lobster processing industries in Pernambuco state, Brazil. Both industries manufacture three products including frozen whole lobsters, frozen whole cooked lobsters, and frozen lobster tails. Industry A is located in Recife (Pernambuco, Brazil) and has 553 employers processing approximately 80 tons of lobster/ month, and industry B is located in Jaboatão dos Guararapes (Pernambuco, Brazil) and has 135 employers processing approximately 30 tons of lobster/month.

This research included the following phases: i) technical visit, ii) development and application of the hygienic-sanitary checklist, iii) evaluation of the data obtained by the checklist application and organization based on the changes necessary to meet the specifications and comply with the current Brazilian legislation, and iv) design of the HACCP plan (EFSTRATIADIS; ARVANITOYANNIS, 2000; VIEIROS et al., 2009).

\subsection{Technical visit to analyze the industries}

The technical visit to the industries occurred on the scheduled date to verify the labor organizational system, physical structures, environmental structures, developed activities, and production flow in each processing plant. These observations were important for the creation and development of the hygienic-sanitary checklist and inclusion of all of the legislation modules and respective items and sub-items. Moreover, these items were adjusted to the specificities of each industry.

\subsection{Development and application of the checklist on hygienic-sanitary working practices}

The checklist used in this study was developed using a previous checklist developed by the Ministry of Agriculture, Livestock and Supply (Brazil) based on the recommendations of Codex Alimentarius Commission (CODEX..., 2003) and Brazilian regulations $n^{\circ} 1428 / 93$ (BRASIL, 1993), 326/97 (BRASIL, 1997a), 368/1997 (BRASIL, 1997b) and 275/02 (BRASIL, 2002). The general structure, items, sub-items, and answer options were adopted according to these previous recommendations to create the classification criteria.

The applied checklist includes 41 items and 155 sub-items divided into the following five modules: physical facilities and environment (composed of eighteen items and seventy subitems); equipment and materials (composed of three items and twenty-one sub-items); food handlers (composed of five items and fourteen sub-items); production and food transport (composed of five items and thirty-three sub-items); and documents and records (composed of ten items and seventeen sub-items).

The answer options for the checklist were as follows: "yes", when the analyzed sub-item was in conformity; "no", when the analyzed sub-item was in nonconformity; and "not applicable", when the sub-item was known as not provided in that specific industry. The classification scale for each industry was organized in a quantitative and qualitative order regarding the percentage of conformities according to the recommendation described in the applied hygienic-sanitary checklist, as follows: group one, $76-100 \%$ of the sub-items were in conformity (very good); group two, $75-50 \%$ of the sub-items were in conformity (acceptable); and group three, less than $50 \%$ of the sub-items were in conformity (not acceptable).

Initially, the checklist was tested during a pilot visit to each industry in December 2009 aiming to verify the adequacy of the tool based on the following parameters: understanding of the analyzed items and sub-items by the evaluator and verify whether they correspond to the proposed analysis, their organizational structure, and adequacy of the terms and their easiness of application and interpretation. After the pilot test, the entire checklist was revised and discussed with other researchers and technicians regarding its adherence to the legal requirements and the desired perspective for diagnosis of the GMP/SSOP as well as the appropriate background for the design of the HACCP plan for the industries included in this study. 
Next, the checklist was applied in person by one of the researchers at each industry through direct observation in three different visits at monthly intervals between January and March 2010. A printed version of the checklist was used, and the data were later entered into the computer software (Excel ${ }^{\circ}$ spreadsheet) that included all modules (items and sub-items) and their possible answers. The modules were evaluated by automatically calculating the respective scores and classifications.

\subsection{Design of the HACCP plan for the industries studied}

The design of the HACCP plan started only when all hygienic-sanitary flaws for each industry were met after the application of a hygienic-sanitary checklist to guarantee previous compliance with the GMP/SSOP pre-requisites. The HACCP plan was applied covering all stages of processing from obtaining raw materials to delivering the end products. The HACCP plan was designed according to the Codex Alimentarius Commission (CODEX..., 1997). The HACCP plan covered the following principles: formation of the HACCP team; description of the products manufactured in the industries; construction of a process flow diagram for each product; creation of a list of the steps involved in the process where significant hazards occur and a description of the corresponding preventive measures; identification of each critical control point (CCP); determination of the critical limit for preventive measures associated to each CCP; establishment of corrective actions to be taken for every deviation from a critical limit; establishment of effective record-keeping procedures and files; and establishment of procedures for the verification of proper functioning of the HACCP plan.

\section{Results and discussion}

\subsection{Hygienic-sanitary working practices}

The application of the hygienic-sanitary checklist in the visited industries resulted in conformity rates over $96 \%$ to the sub-items analyzed, thus classification them as group one (very good). Non-conformities were observed only in the physical facilities and environment module for both industries. The percentage of nonconformity was 5.71 and $7.14 \%$ for industries $\mathrm{A}$ and $\mathrm{B}$, respectively. Industry A received nonconformity in four out of the seventy analyzed sub-items of the physical facilities and environment module as follows: shape of the floor (the floor presented some damage due to the friction caused by continuous use of wheeled carts in the processing area); food residues (garbage cans were manually labeled and there was no specific identification for them); and the records containing information regarding the frequency of cleaning and maintenance of acclimatization (air conditioning) systems available for easy access to the processing area (information was only available in the files located in the maintenance area)

For industry $\mathrm{B}$, the nonconformities were found in the following five (7.14\%) sub-items of the physical facilities and environment module: use of arched angles between the walls and roof as well as between the walls and floor (because right angles were noted for all locations); food residues (garbage cans were manually labeled and there was no specific identification for them); the records containing information regarding the frequency of cleaning and maintenance of acclimatization (air conditioning) for easy access to the processing area (information was only available in the files located in the maintenance area); and hand-washing stations (they were missing in the processing area and were only present in an area called hygienic cabinet); and an inadequate number (and location) of hand-washing stations and absence of a hand-washing procedures.

The inadequate number and location of hand-washing stations as well as hand-washing procedures for industry $B$ demanded immediate correction due to the risk of compromising the quality and safety of the processed foods. The importance of effective hand washing and drying for the control of microbial cross contamination and occurrence of microbial foodborne diseases is commonly understood (VIEIROS et al., 2009; NUNES et al., 2010). The effective decrease in skin surface microbial counts caused by the various stages of a proper handwashing procedure has been previously documented (BORGES; SILVA; GONTIJO FILHO, 2007).

Contaminated hands are considered to be one of the main causes of foodborne disease outbreaks since contaminated hands are reservoirs for various pathogens, such as Staphylococcus spp., Salmonella spp., and Escherichia coli. Many studies have reported unsatisfactory hygienic practices of food handlers (HENROID JUNIOR; SNEED, 2004; AARNISALO et al., 2006) and outbreaks caused by them (DUNCANSON; WAREING; JONES, 2003; KISHIMOTO et al., 2004).

The design of the HACCP system for the lobster processing industries studied started when all of the hygienic-sanitary flaws for the physical facilities and environment module were detected after application of the hygienic-sanitary checklist aiming to guarantee the compliance with the GMP/SSOP prerequisites. The success and effectiveness of the HACCP plan in preventing foodborne diseases and risks to consumer's health depend on the proper combined application of the GMP and SSOP programs (ROBERTO; BRANDÃO; SILVA, 2006).

Compliance with the GMP/SSOP pre-requisites in food processing plants ensures favorable conditions for safe product manufacturing, which reduces the number of CCPs and results in a simpler HACCP plan (LUPIN; PARIN; ZUGARRAMUNDI, 2010). The reduction in identified CCPs due to the compliance with the previous GMP/SSOP pre-requisites in food industries is known to directly interfere with the resources necessary to implement, develop, and maintain the HACCP plan, which improves the economic viability and maintenance of the industries (ROBERTO; BRANDÃO; SILVA, 2006; ZUGARRAMUNDI et al., 2007).

\subsection{Developing the HACCP plan for lobster industries}

\section{Formation of the HACCP team}

The HACCP team for the industries consisted of the following members: 
1. Quality control and quality assurance manager (head);

2. Incoming material manager;

3. Production manager;

4. Quality control assistant;

5. Packaging and storage assistant.

Efstratiadis and Arvanitoyannis (2000) reported that the skills of those forming the HACCP team is of primary concern for its proper development because the appropriate team provides the required technical skills for implementation of the HACCP system and it helps people change their attitudes when necessary.

\section{Product description}

The description of the products processed in the industries included in this study is shown in Table 1. Both industries process the three following different products: frozen whole lobster, frozen whole cooked lobster, and frozen lobster tail. The two main physicochemical characteristics of these products are the $\mathrm{pH}$ values, which range from 6.8 to 7.0 , and the water activity, which is higher than 0.98 . The neutral $\mathrm{pH}$ and high water activity enable spoilage and pathogenic microorganisms to multiply in these products, thus increasing the risk of deterioration and occurrence of foodborne diseases.

The lobsters processed by these industries were captured along the Northeastern coast of Brazil; they were transported by fishing boats in three different forms, as follows: live (higher value), dead whole and tail. The lobsters received by the industries belonged to three species of spiny lobster, including $P$. argus, $P$. laevicauda, and P. echinatus. The form of their transportation depended on the trapping method used and the number of days spent fishing without coming back to the coast, and method of preservation available in the boat. All lobster suppliers were registered at both industries which were required to develop a SSOP for sanitization and control of insects in their boats.

\section{Construction of processing flow diagram}

The process flow diagrams for the production of frozen whole lobsters, frozen whole cooked lobsters and frozen lobster tails in the two Brazilian lobster processing industries are shown in Figures 1,2 and 3, respectively. The integrity and thoroughness of the process flow diagram used is of great importance because the hazard analysis is performed based on this diagram. The members of the HACCP team must be responsible for this construction and online verification with the aim to develop an accurate figure of the process, including all stages starting from incoming raw materials to the obtainment and storage of the end product (EFSTRATIADIS; ARVANITOYANNIS, 2000).

The processing flow diagrams of each lobster form for the three industries were constructed into one diagram. When individual particularities in a particular step of the processing were verified for a specific industry, they were highlighted in the processing flow diagram (dotted line).

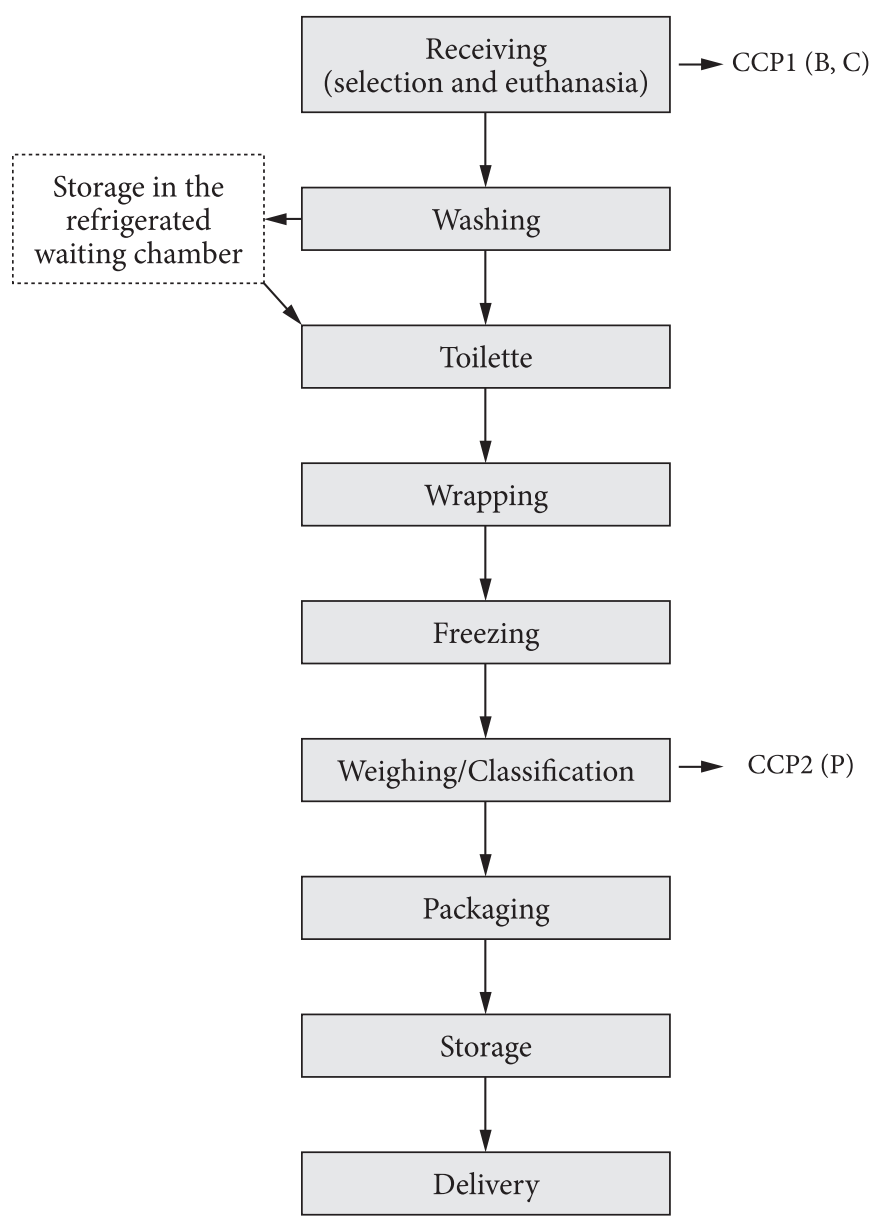

Figure 1. Process flow diagram of frozen whole lobster in Brazilian lobster processing industries. CCP, Control Critical Point; B, Biological; C, Chemical; and P, Physical.

Table 1. Product description.

\begin{tabular}{ll}
\hline Products & frozen whole lobster, frozen whole cooked lobster, and frozen lobster tail \\
Incoming raw materials & live lobster, whole dead lobster, and lobster tail \\
Additives & tripolyphosphate \\
Packaging & wrapping in plastic bags and packaging in cardboard boxes \\
Storage and delivery methods & stored and delivered in boxes under freezing conditions \\
Product use & consumed in roasted preparations, stew, or fried preparations \\
Consumers & general public \\
\hline
\end{tabular}




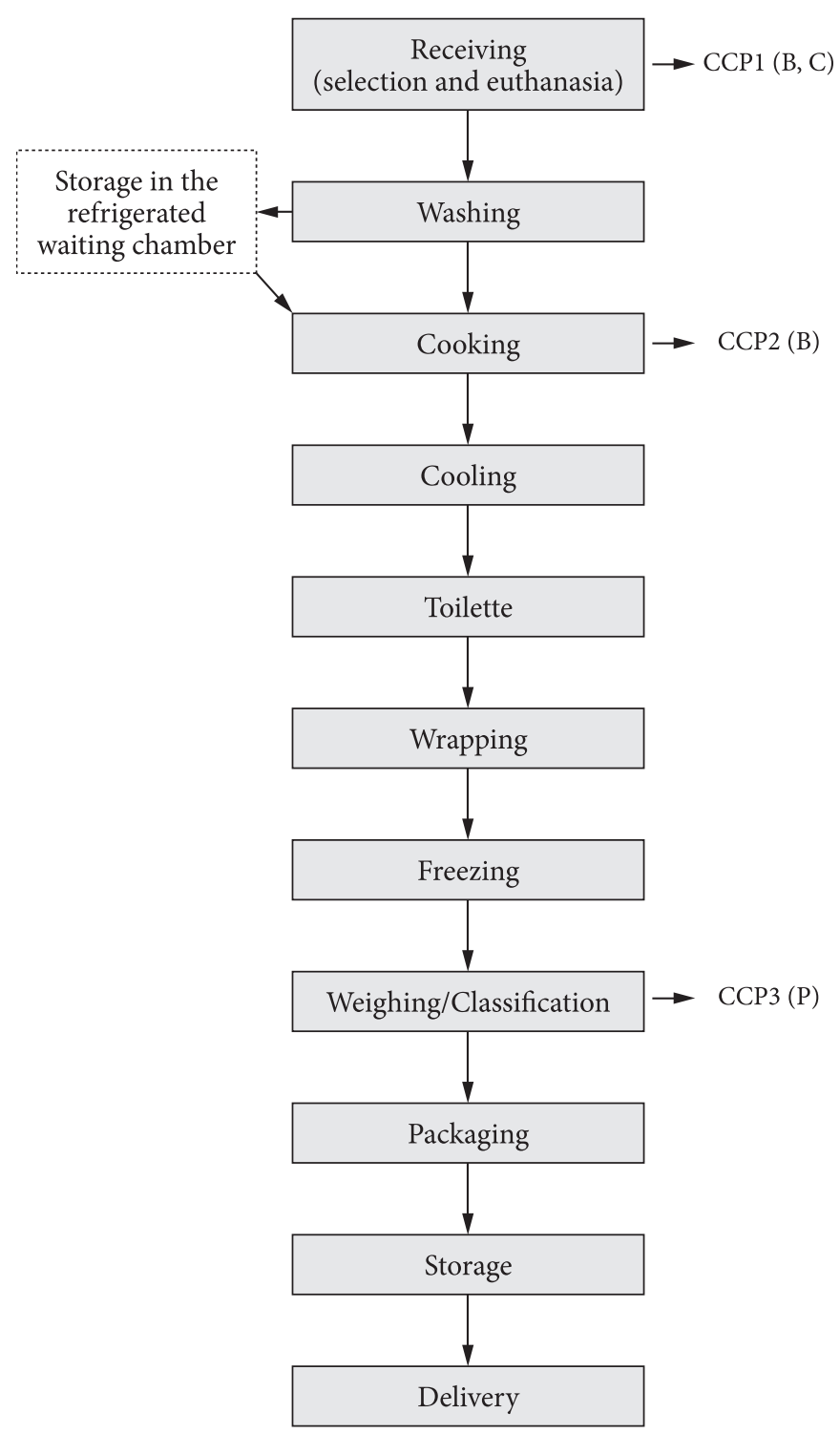

Figure 2. Process flow diagram of frozen whole cooked lobster in Brazilian lobster processing industries. CCP, Control Critical Point; $\mathrm{B}$, Biological; C, Chemical; and P, Physical.

\section{Identification of possible hazards and related preventive measures}

The CCPs related to the processing of frozen whole lobsters, frozen whole cooked lobsters and frozen lobster tails in the two Brazilian industries are shown in Table 2. Incoming raw materials (such as lobsters and tripolyphosphate additive), wrapping materials, and packaging materials reached the companies by a proper department of incoming materials in appropriate containers (tripolyphosphate and wrapping/packaging materials) and boxes. The wrapping and packaging materials were purchased based on the previously agreed specifications from the certified suppliers, who were continuously inspected and reviewed regarding the material quality and availability.

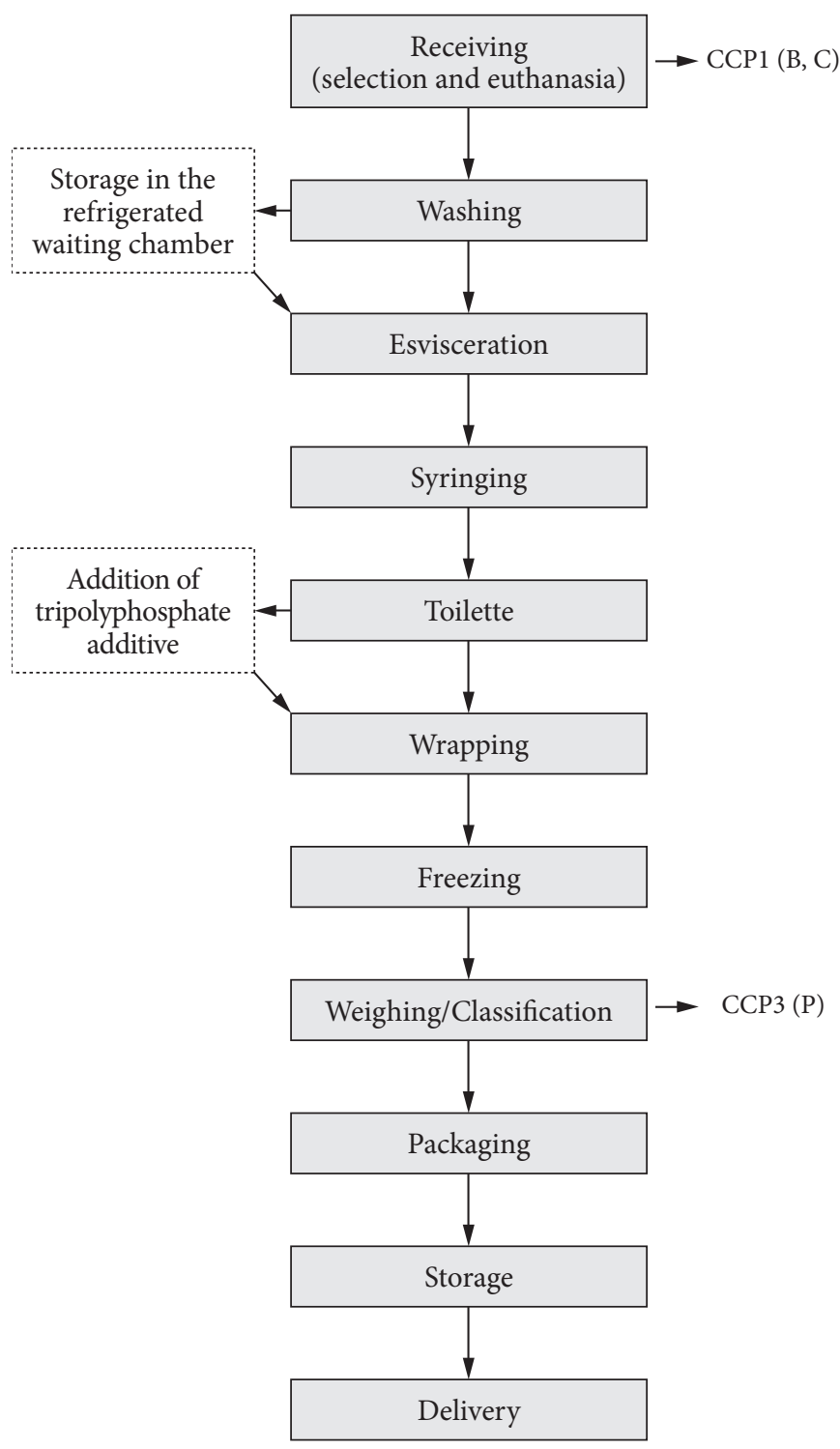

Figure 3. Process flow diagram of frozen lobster tail in Brazilian lobster processing industries. CCP, Control Critical Point; B, Biological; C, Chemical; and P, Physical.

The incoming whole dead lobsters and lobster tails reached the company in polyethylene boxes containing ice. Live lobsters were immersed in seawater with added ice (approximate temperature of $8{ }^{\circ} \mathrm{C}$ ) and selected for processing as whole cooked lobster or whole frozen lobster. After this verification, live lobsters were euthanized in the "dirty" area by heat shock using refrigerated water $\left(2-4^{\circ} \mathrm{C}\right)$ for 5 minutes.

The incoming dead lobsters were used as raw material for the manufacture of frozen lobster tails. Dead lobsters had their heads removed and were subjected to the same quality criteria applied to the incoming lobster tails. Incoming dead lobsters and tails were verified for temperature, which must be lower than $4^{\circ} \mathrm{C}$. In the case of non-conformance (temperatures higher than $4^{\circ} \mathrm{C}$ ), the quality control manager suggested the addition of ice if the detected temperature was between $5-8^{\circ} \mathrm{C}$ or their return 
Table 2. Determination of Critical Control Point related to the processing of frozen whole lobster, whole cooked lobster, and frozen tail lobster in Brazilian processing industries.

\begin{tabular}{|c|c|c|c|c|c|c|c|}
\hline Stage of processing & Hazard & $\mathrm{Q} 1^{\mathrm{a}}$ & $\mathrm{Q}^{\mathrm{b}}$ & $\mathrm{Q}^{\mathrm{c}}$ & $\mathrm{Q}^{\mathrm{d}}$ & $\mathrm{Q}^{\mathrm{e}}$ & $\mathrm{CCP}^{\mathrm{f}}$ \\
\hline \multirow[t]{3}{*}{ Raw material receiving and washing } & $\begin{array}{l}\text { 1. Biological: multiplication of pathogenic } \\
\text { microorganisms; melanosis. }\end{array}$ & 1.No & 1.Yes & & & & 1.CCP $(B)^{g}$ \\
\hline & 2. Physical: glass; wood, etc. & 2.Yes & - & - & - & - & 2.No \\
\hline & $\begin{array}{l}\text { 3. Chemical: presence of preservatives (sodium } \\
\text { metabisulfite in tail); diesel oils and grease. }\end{array}$ & 3.No & 3.Yes & 3.No & 3. Yes & 3.No & 3.CCP $(\mathrm{C})^{\mathrm{h}}$ \\
\hline $\begin{array}{l}\text { Evisceration } \\
\text { (only for frozen cooked tail) }\end{array}$ & 1. Biological: microbial contamination by handling. & 1.Yes & - & - & - & - & 1.No \\
\hline $\begin{array}{l}\text { Syringing } \\
\text { (only for frozen cooked tail) }\end{array}$ & $\begin{array}{l}\text { 1. Biological: multiplication of pathogenic } \\
\text { microorganisms; possibility of contamination by } \\
\text { handling. }\end{array}$ & 1.Yes & - & - & - & - & 1.No \\
\hline $\begin{array}{l}\text { Cooking } \\
\text { (only for frozen whole cooked lobster) }\end{array}$ & $\begin{array}{l}\text { 1. Biological: survival of pathogenic and } \\
\text { microorganisms. }\end{array}$ & 1.No & 1.Yes & 1.Yes & - & - & 1.CCP (B) \\
\hline $\begin{array}{l}\text { Cooling } \\
\text { (only for frozen whole cooked lobster) }\end{array}$ & 1. Biological: recontamination of the product. & 1.Yes & - & - & - & - & 1.No \\
\hline \multirow{2}{*}{$\begin{array}{l}\text { Toilette } \\
\text { (Addition of additive to the tail) }\end{array}$} & 1. Biological: microbial contamination by handling. & 1.Yes & - & - & - & - & 1.No \\
\hline & $\begin{array}{l}\text { 2. Chemical: excessive application of } \\
\text { tripolyphosphate - Industry A). }\end{array}$ & 2.No & 2.Yes & 2.No & 2.No & - & 2.No \\
\hline Wrapping & 1. Biological: microbial contamination by handling. & 1.Yes & 1.Yes & - & - & - & 1.No \\
\hline Frozen & $\begin{array}{l}\text { 1. Biological: possibility of multiplication of } \\
\text { microorganisms because inefficient frozen. }\end{array}$ & 1.Yes & - & - & - & - & 1.No \\
\hline \multirow[t]{2}{*}{ Weighting/classification } & $\begin{array}{l}\text { 1. Biological: possibility of microbial cross } \\
\text { contamination. }\end{array}$ & 1.Yes & - & - & - & - & 1.No \\
\hline & 2. Physical: error in weighting and classification. & 2.No & 2.Yes & 2.No & 2.No & 2.No & 2.CCP $(\mathrm{P})^{\mathrm{i}}$ \\
\hline Packaging & No hazard. & - & - & - & - & - & 1.No \\
\hline Storage & $\begin{array}{l}\text { 1. Biological: multiplication of pathogenic } \\
\text { microorganisms. }\end{array}$ & 1.Yes & - & - & - & - & 1.No \\
\hline Delivery & No hazard. & - & - & - & - & - & 1.No \\
\hline
\end{tabular}

${ }^{a} \mathrm{Q} 1$ (Question 1): Is the hazard controlled by the pre-requisites program?; ${ }^{\mathrm{b}} \mathrm{Q} 2$ (Question 2): Do preventive measures exist for the identified hazard?; ${ }^{\mathrm{c}} \mathrm{Q} 3$ (Question 3): Could the step reduce or eliminate the hazard to acceptable levels?; ${ }^{\mathrm{d}} \mathrm{Q} 4$ (Question 4): Could contamination increase to unacceptable levels?; ${ }^{\mathrm{e}} \mathrm{Q} 5$ (Question 5): Will a subsequent step or action eliminate or reduce the hazard to a acceptable level?; ${ }^{\mathrm{f}} \mathrm{CCP}$ : Control Critical Points; ${ }^{\mathrm{B}} \mathrm{B}-\mathrm{Biological} ;{ }^{\mathrm{h}} \mathrm{C}$ : Chemical; ${ }^{\mathrm{P}}$; Physical.

to the suppliers as non-conforming when the temperature was higher than $8{ }^{\circ} \mathrm{C}$. The received lobsters were also inspected for appropriate sensory characteristics, and these parameters were recorded in the proper files.

The lengths of the lobster tails were measured using a proper caliper rule. The current Brazilian legislation establishes a minimum tail length of 13 and $11 \mathrm{~cm}$ for $P$. argus and $P$. laevicauda, respectively, as acceptable for capture and market (BRASIL, 2006). The tails were sampled (two for each supplier), and the sodium metabisulfite levels were analyzed using a rapid assay using a standard reagent strip. The concentration of sodium metabisulfite must be lower than 100 ppm according to standard and compulsory instructions (CODEX..., 1981; BRASIL, 1985). If the sodium metabisulfite levels were higher than $100 \mathrm{ppm}$, the incoming materials were rejected and returned to the suppliers as non-conforming.

The receiving process was the CCP related to the biological and chemical hazards for all lobster forms. The biological hazard was related to the possible multiplication of spoilage and pathogenic microorganisms because the preventive measures included the control of temperature and application of GMP in this stage. The chemical hazards were related to the excess of sodium metabisulfite and presence of grease and diesel oil, which were used as preventive measures for the chemical control (quantification of sodium metabisulfite) before processing and application of GMP in the capture and washing of the products, respectively. In the case of sodium metabisulfite levels higher than 100 ppm, the batches must be rejected.

The washing step was performed by immersion in refrigerated water $\left(2-10{ }^{\circ} \mathrm{C}\right)$ containing sodium hypochlorine ( 5 ppm) for 5 minutes in stainless steel containers. After the washing step, the lobster materials were placed in polypropylene boxes containing ice flakes and identified for each supplier. The washed material was then transferred to the processing area. Extra materials were stored in a refrigerated waiting room before being transferred to the processing area.

To obtain the tails, the dead lobsters were eviscerated in the processing area using a stainless steel stiletto to remove their enteric channels. The eviscerated lobsters were submitted to the syringing step to remove residual dirt in the hole obtained as a result of the removal of the enteric channel by high-pressure water using sharp faucets. 
To obtain the whole cooked lobsters, the selected lobsters were submitted to cooking in water containing sodium hypochlorite $(200 \mathrm{ppm})$ and sodium chlorine $(50 \mathrm{~g} / \mathrm{L})$. The lobsters with weight ranging from 350 to $450 \mathrm{~g}$ were cooked for 15 to 20 minutes, respectively. The lobsters were then placed in stainless steel tanks with refrigerated and chlorinated (200 ppm) water for cooling. The cooking step was regarded as a Critical Control Point (CCP) for the processing of whole cooked lobster due to the possibility of survival of some pathogenic microorganisms (biological hazard) because the preventive measures adopted must be the introduced continuously in the assembly line keeping control of time and temperature at this stage of production. In the case of a strong deviation, the batch must be rejected, and investigations initiated to determine the cause leading to the non-conformance.

Proper cooking step assures the complete inactivation of polyphenol oxidase, which prevents the darkening (melanosis) of the hepatopancreas and meat during storage. Polyphenol oxidase is responsible for much of the melanosis observed in crustaceans, and it is naturally present in the hemolymph and viscera of the lobster (SOMOZA et al., 2008).

To obtain the frozen whole lobster, only the washing step after receipt of the lobsters was applied. Following the completion of cooking step, all lobster forms were cleansed to remove some membranes or residual dirt using stainless steel scissors and nylon brushes.

For the lobster tails, industries apply sodium tripolyphosphate following the toillet (step to increase the water retention and to protect against oxidative rancidity (TZOUROS; ARVANITOYANNIS, 2000). This additive was used only by industry A at $300 \mathrm{ppm}$, and $10 \mathrm{~g} / \mathrm{kg}$ diphosphorus pentoxide $\left(\mathrm{P}_{2} \mathrm{O}_{5}\right)$ was not exceeded, as suggested by the Codex Alimentarius Commission (CODEX..., 1981). After this step was completed, the tails were individually wrapped in plastic bags, placed on polypropylene trays, and exposed to the forced-air-freezing tunnel $\left(-30\right.$ to $\left.-40{ }^{\circ} \mathrm{C}\right)$ for approximately 8 hours. The whole lobsters were placed into plastic bags, carefully wrapped with a sealing strip, immobilized to avoid the loss of paws and antennas, and submitted to the same freezing procedure applied for tails.

Frozen wrapped materials were weighted and manually classified according to the individual weight for whole lobsters, and the tails were classified according to their length (2-9, 10-12, 12-14, 16-20, 20-24 and greater than $24 \mathrm{~cm}$ ). Classified whole lobsters were packaged in waterproof cardboard boxes with a capacity of $10 \mathrm{lb}$. At this point, the classified tails were initially placed in waterproof cardboard boxes with a capacity of $10 \mathrm{lb}$ of net weight, and they were then finally packaged in corrugated cardboard boxes with a capacity of $40 \mathrm{lb}$ ( 4 units per $10 \mathrm{lb}$ ). Information regarding the production factory and end products, including the manufacturing data, expiration data (12-18 months under -18 to $-24^{\circ} \mathrm{C}$ ), batch number, species, and weight of lobster, was automatically printed on the exterior of the boxes.

The weighing and classification corresponded to a physical CCP for all lobster forms when considering the possibility of differences occurring between the actual weight and classification, and this information was included on the label. The differences between the actual weight and reported weight are characterized as economic fraud. To control this CCP, an efficient program for maintenance, calibration, and gauging of the instrumentation used in the weighting stage was adopted and conducted by trained personnel. Moreover, random sampling of batches was implemented for control. In the case of deviation, the process must be stopped to investigate the cause leading to the non-conformance.

The end products were transported to the storage room, where they were kept at -18 to $-24^{\circ} \mathrm{C}$ until delivery. The end products were delivered in containers with temperatures below $-18{ }^{\circ} \mathrm{C}$ to the sea port or other destinations for commercialization.

All stages known as CCPs, occurring hazards, corresponding monitoring strategies, corrective actions, and responsible personnel are shown in Table 3.

\section{HACCP plan documents and records}

Several documents were prepared on a pre-established interval according to their purpose of control and related to the following: 1) HACCP plan in the current state and description of existing amendments; 2) monitoring and maintenance of files for CCP deviations and corrective actions undertaken (including information regarding hold and batch recall); 3) training records presenting the continuous training of the personnel; 4) auditing records for non-conforming cases; and 5) calibration records related to instrumentation used for the processing of the different products.

The records were created in a typed format and kept on a daily basis (CCP monitoring) or whenever needed (e.g., corrective procedures), and the records were held for a minimum time of 3 years. Effective record keeping by companies is an essential aspect to provide documentation for the purposed HACCP plan implementation and accompaniment of its correct execution (WANG et al., 2010).

\section{Verification and maintenance}

An internal auditing was performed in the companies every two months by the head of the HACCP team because record files were kept for use as future references. When the absence of specifications regarding specific situations were noted, detailed documents describing the problem and possible causes were prepared and filed for future reference. Corrective actions for each CCP were predicted in the case of deviations, as described for each processing step known as individual CCPs in the HACCP plan. The onsite inspection of the CCP records was performed on a weekly basis. Documentation of the control and revision of responses to the existing customer complaints and some serious incidents that occurred were created and organized in separate files. According to Efstratiadis and Arvanitoyannis (2000), the adoption of this practice improves the public image of a food company (regarded as the client/ company relationship), worker productivity, and worker safety. 


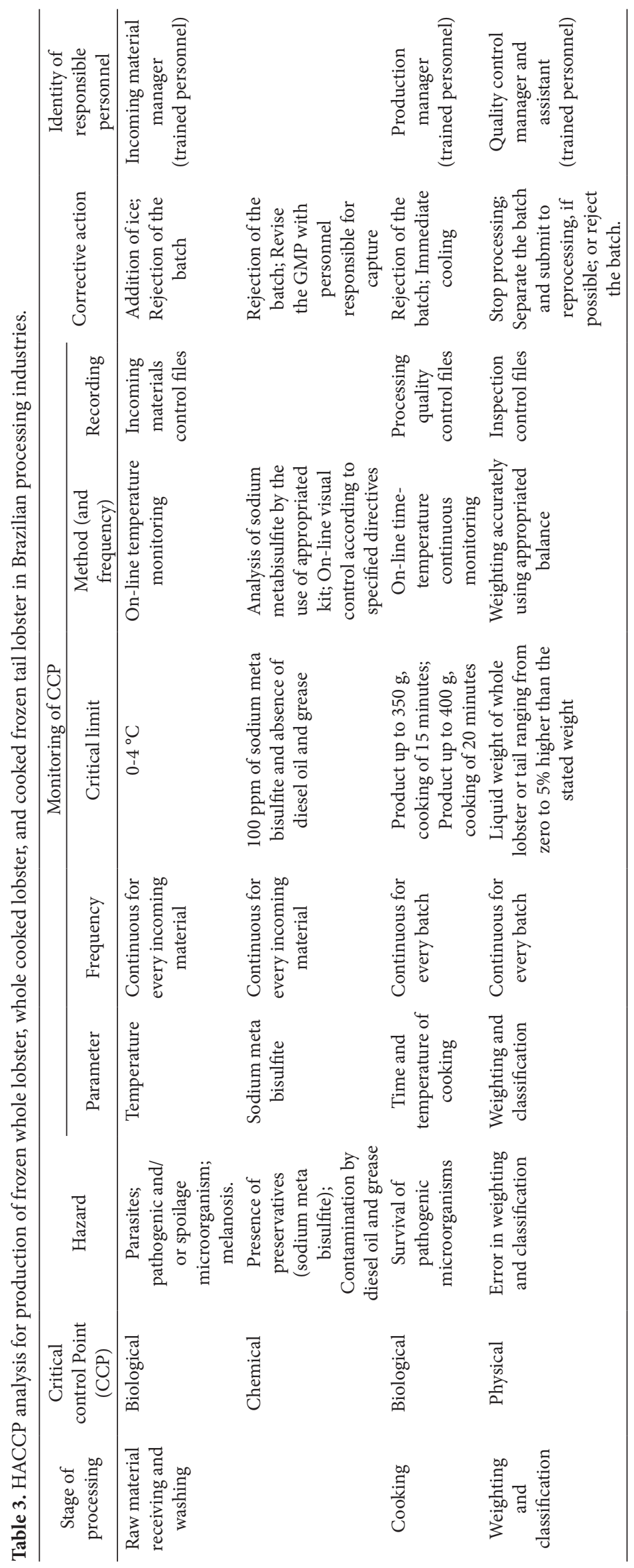




\section{Conclusions}

The application of the hygienic-sanitary checklist showed that the lobster processing industries studied had a satisfactory control of their processing practices and were classified as group one (very good). For both industries A and B, the nonconformities were detected only in the physical facilities and environment module. All detected non-conformities were corrected prior to the development of the HACCP plan to support its implementation and efficacy. The HACCP plan development resulted in the detection of two CCPs in the processing of frozen whole lobster and frozen lobster tails, which included the receiving (biological and chemical hazard) and classification (physical hazard) steps. An additional CCP identified in the cooking step (biological hazard) was detected for the frozen whole cooked lobster. The proper implementation of the HACCP system in these industries in compliance with all pre-requisites provides an essential part of a total quality system and subsequently results in a more effective control of the hazards along the processing lines with the establishment of the following measures: corrective measures, which must be instantaneously adopted when deviations are detected; training and continuous education on sanitary practices of personnel; and auditing and record-keeping procedures in pre-established intervals that ensure the proper functioning of the system. By implementing this plan, the studied lobster processing plants may have experienced a reduction in total costs and an increase in the end product quality over time, thereby reinforcing their competitiveness in the current context of the fishery industry and market.

\section{References}

AARNISALO, K. et al. The hygienic working practices of maintenance personnel and equipment hygiene in Finish food industry. Food Control, v. 17, n. 12, p. 1001-1011, 2006. http://dx.doi.org/10.1016/j. foodcont.2005.07.006

BELL, N. J. et al. The development, implementation and testing of a lameness control program based on HACCP principles and designed for heifers on dairy farms. The Veterinary Journal, v. 180, n. 2, p. 178-188, 2009. http://dx.doi.org/10.1016/j.tvjl.2008.05.020

BORGES, L. F., SILVA, B. L.; GONTIJO FILHO, P. P. Hand washing: Changes in the skin flora. American Journal of Infection Control, v. 35, n. 6, p. 417-420, 2007. http://dx.doi.org/10.1016/j. ajic.2006.07.012

BRASIL. Ministério da Saúde. Decreto-Lei no 25/85, de 18 de janeiro de 1985. Autoriza e estabelece a quantidade a aplicar nos crustáceos, no estado cru e em fresco, de sulfito de sódio (E 222), metabissulfito de sódio (E 223) e metabissulfito de potássio (E 224). Diário Oficial da República Federativa do Brasil, Brasília, DF, 18 jan. 1985.

BRASIL. Ministério da Saúde. Agência de Vigilância Sanitária. Regulamento no 1.428 , de 26 de novembro de 1993. Regulamento Técnico para Inspeção Sanitária de Alimentos, Diretrizes para o Estabelecimento de Boas Práticas de Produção e de Prestação de Serviços na Área de Alimentos e Regulamento Técnico para o Estabelecimento de Padrão de Identidade e Qualidade (PIQ's) para Serviços e Produtos na Área de Alimentos. Diário Oficial da República Federativa do Brasil, Brasília, DF, 2 dez. 1993.

BRASIL. Ministério da Saúde. Agência de Vigilância Sanitária. Regulamento n 326, de 30 de julho de 1997. Regulamento técnico sobre as condições higiênico-sanitárias e de boas práticas de fabricação para estabelecimentos produtores/industrializadores de alimentos. Diário Oficial da República Federativa do Brasil, Brasília, DF, 1 out. 1997a.

BRASIL. Ministério da Saúde. Agência de Vigilância Sanitária. Regulamento ${ }^{\circ} 368$, de 4 setembro de 1997. Regulamento técnico sobre as condições higiênico-sanitárias e de boas práticas de fabricação para os estabelecimentos elaboradores/industrializadores de alimentos. Diário Oficial da República Federativa do Brasil, Brasília, DF, 8 set. 1997 b.

BRASIL. Ministério da Saúde. Agência de Vigilância Sanitária. Regulamento $n^{\circ} 275$, de 21 de outubro de 2002. Regulamento Técnico de Procedimentos Operacionais Padronizados aplicado aos estabelecimentos produtores/industrializadores de alimentos e a lista de verificação das Boas Práticas de Fabricação em estabelecimentos produtores/industrializadores de alimentos. Diário Oficial da República Federativa do Brasil, Brasília, DF, 23 out. 2002. Seção 1, n. 206, p. 126.

BRASIL. Instituto Brasileiro do Meio Ambiente e dos Recursos Naturais Renováveis. Instrução Normativa nº 138, de 6 de dezembro de 2006. Dispõe sobre os comprimentos mínimos das lagostas Panulirus argus e $P$. laevicauda e dá outras providências. Diário Oficial da República Federativa do Brasil, 7 dez. 2006. n. 234.

CODEX ALIMENTARIUS COMMISSION - CAC. CODEX STAN 95-1981: Codex standard for quick frozen lobsters. 1981. 6 p. Disponível em: <http://www.seafood.nmfs.gov/../CODEX\%20 Standards/Frozen_Lobsters.pdf $>$. Accesso em: 12 fev. 2010.

CODEX ALIMENTARIUS COMMISSION - CAC. Hazard Analysis Critical Control Points (HACCP): system guide-lines for its application. Roma, 1997. Disponível em: <http://www.fao.org/ docrep/005/y1579e/y1579e03.htm>. Acesso em: 15 mar. 2010.

CODEX ALIMENTARIUS COMMISSION - CAC. Recommended international code of practice general principles of food hygiene. RCP 1-1969. 4. rev. 2003. 31 p. Disponível em: <http://www. codexalimentarius.net/download/standards/23/cxp_001e.pdf $>$. Accesso em: 13 jan.10.

DUNCANSON, P.; WAREING, D. R. A.; JONES, O. Application of an automated immunomagnetic separation-enzyme immunoassay for the detection of Salmonella spp. during an outbreak associated with a retail premises. Letters in Applied Microbiology, v. 37, n. 2, p. 144-148, 2003. http://dx.doi.org/10.1046/j.1472765X.2003.01365.X

EFSTRATIADIS, M. M.; ARVANITOYANNIS, I. S. Implementation of HACCP to large scale production line of Greek ouzo and brandy: a case study. Food Control, v. 11, n. 1, p. 19-30, 2000. http://dx.doi. org/10.1016/S0956-7135(99)00053-5

GÓES, C. A.; LINS-OLIVEIRA, J. E. Natural diet of the spiny lobster, Panulirus echinatus Smith, 1869 (Crustacea: Decapoda: Palinuridae), from São Pedro and São Paulo Archipelago, Brazil. Brazilian Journal of Biology, v. 69, n. 1, p. 143-148, 2009. http:// dx.doi.org/10.1590/S1519-69842009000100018

HENROID JUNIOR, D.; SNEED, J. Readiness to implement hazard analysis and critical control point (HACCP) systems in Iowa schools. Journal of the American Dietetic Association, v. 104, n. 2, p. 180-185, 2004. http://dx.doi.org/10.1016/j.jada.2003.11.009

KISHIMOTO, M. et al. Ribotyping and a study of transmission of Staphylococcus aureus collected from food preparation facilities. Journal of Food Protection, v. 67, n. 6, p. 1116-1122, 2004.

LUPIN, H. M.; PARIN, M. A.; ZUGARRAMUNDI, A. HACCP economics in fish processing plants. Food Control, v. 21, n. 8, p. 1143-1149, 2010. http://dx.doi.org/10.1016/j.foodcont.2010.01.009 
NUNES, B. N. et al. A survey on the sanitary condition of commercial foods of plant origin sold in Brazil. Food Control, v. 21, n. 1, p. 50-54, 2010. http://dx.doi.org/10.1016/j.foodcont.2009.03.016

OGAWA, M.; ITÓ, L. S.; MELO, F. E. A. Electric paralyzation and reduction of weight loss in the processing, of roundcooked spiny lobsters. Ciência e Tecnologia de Alimentos, v. 27, n. 1, p. 125-129, 2007. http://dx.doi.org/10.1590/S010120612007000100022

POUMEYROL, G. et al. HACCP methodology implementation of meat pâté hazard analysis in pork butchery. Food Control, v. 21 , n. 11 , p. 1500-1506, 2010. http://dx.doi.org/10.1016/j. foodcont.2010.03.017

ROBERTO, C. D.; BRANDÃO, S. C. C.; SILVA, C. A. B. Costs and investments of implementing and maintaining HACCP in a pasteurized milk plant. Food Control, v. 17, n. 8, p. 589-603, 2006. http://dx.doi.org/10.1016/j.foodcont.2004.05.011

SOMOZA, R. D. et al. Lobster (Panulirus argus) captures and their relation with environmental variables obtained by orbital sensors for cuban waters (1997-2005). Brazilian Journal of Oceanography, v. 56, n. 3, p. 225-237, 2008. http://dx.doi.org/10.1590/S167987592008000300007
TZOUROS, N. E.; ARVANITOYANNIS, I. S. Implementation of Hazard Analysis Critical Control Points (HACCP) systems to the fish/seafood industry: a review. Food Review International, v. 16, n. 3, p. 273-325, 2000. http://dx.doi.org/10.1081/FRI-100100290

VIEIROS, M. B. et al. Food safety practices in a Portuguese canteen. Food Control, v. 20, n. 10, p. 936-941, 2009. http://dx.doi. org/10.1016/j.foodcont.2009.02.002

WANG, D. et al. Application of hazard analysis critical control points (HACCP) system to vacuum-packed sauced pork in Chinese food corporations. Food Control, v. 21, n. 4, p. 584-591, 2010. http:// dx.doi.org/10.1016/j.foodcont.2009.08.009

YOUN, S.; SNEED, J. Implementation of HACCP and pre-requisites program in school foodservices. Journal of the American Dietetic Association, v. 103, n. 1, p. 55-60, 2003. http://dx.doi.org/10.1053/ jada.2003.50002

ZIGGERS, G. W. HACCP, vertical coordination and competitiveness in the food industry. In: UNNEVEHR, L. J. (Ed.). The economics of HACCP: cost and benefits. St. Paul: Eagan Press, 2000. p. 269-284.

ZUGARRAMUNDI, A. et al. A quality cost model for food processing plants. Journal of Food Engineering, v. 83, n. 3, p. 414-421, 2007. http://dx.doi.org/10.1016/j.jfoodeng.2007.03.029 